EDITORIAL

\title{
WORLD ECONOMIC FORUM: PRESENT AND FUTURE
}

\author{
FORO ECONÓMICO MUNDIAL: PRESENTE Y FUTURO
}

FÓRUM ECONÔMICO MUNDIAL: PRESENTE E FUTURO

\begin{abstract}
Albert-Pol. Miró Pérez
Docente investigador, Facultad de Empresa y Comunicación, Universidad de Vic, ESERP Business School and Law, Barcelona. Mail: albertpol.miro@uvic.cat
\end{abstract}

\section{How to cite this article}

Miró-Pérez, Albert-Pol (2020). World Economic Forum: present and future. Dimensión Empresarial, 18(2). DOI: 10.15665/dem.v18i2.2280

The Swiss town of Davos-Klosters hosted on January 21 the 50 th edition of the World Economic Forum in which politicians, businessmen, as well as representatives of social and cultural organizations met to discuss and find potential solutions to global problems.

But, what are the main challenges projected from the Forum? Broadly speaking, the perspectives of international trade, global economic growth, industry (and revolution) 4.0, the future of multilateralism and the geopolitical order are highlighted. Also, the increasingly present environmental pressures are included, which have become one of the main risks facing the world.

Trying to give a coherent response to these challenges and starting with the economic field, it has been highlighted how an increase in inequality has been generated, this circumstance can lead to a high risk of economic stagnation, as well as an increase in the economic uncertainty that affects clearly to the present and future of international trade. All this circumstance occurs in a new context known as industry 4.0 , based on the digital transformation that directly affects the behavior, structure, and results of economic agents, business models, as well as markets (Bodrozic \& Adler, 2018; Torrent-Sellens, 2019).
La localidad suiza de Davos-Klosters acogió el día 21 de enero la 50a edición del Foro Económico Mundial en la cual se reunieron políticos, empresarios, así como representantes de organizaciones sociales y culturales para debatir y hallar potenciales soluciones a problemas de orden global.

Pero ¿cuáles son los principales desafíos proyectados desde el Foro? A grandes rasgos, se destacan las perspectivas del comercio internacional, el crecimiento económico global, la industria (y revolución) 4.0, el futuro del multilateralismo y el orden geopolítico. Asimismo, también están incluidas las cada vez más presentes presiones medioambientales, que se han convertido en uno de los principales riesgos a los que se enfrenta el mundo.

Intentando dar una respuesta coherente a dichos desafíos y empezando por el ámbito económico, se ha destacado como se ha generado un incremento de la desigualdad, esta circunstancia puede conducir hacia un alto riesgo de estancamiento económico, así como un incremento de la incertidumbre económica que afecta de manera clara al presente y al futuro del comercio internacional. Toda esta circunstancia se da en un nuevo contexto conocido como la industria 4.0, basado en la transformación digital que afecta de manera directa al comportamiento, la estructura y los resultados de los agentes económicos, de los modelos de negocio, así como de los mercados (Bodrozic \& Adler, 2018; Torrent-Sellens, 2019). 
But what does industry 4.0 imply? Robotics, Artificial Intelligence (AI), Internet of things (IOT), mass data, social communication networks, collaborative platforms, among others, are associated towards a business way of acting that allows them to face globalization, to an increasingly intense competition, greater volatility in demand and the need to be innovative (both in product and organizationally) (Francalanza et al., 2018; Belman-López et al., 2019; Torrent-Sellens, 2019).

Although automated work processes with a digital base can replace routine work; The new reality, characterized by the accumulation of capital, as well as cost savings, has led to the generation of non-automated jobs. All this considering the debate associated with the potential for the displacement of workplaces (Frey \& Osborne, 2017).

For these reasons, technology has become an important tool that could lead to the improvement of social welfare through projects to build "smart cities" in the context of "mega-cities". The growth of these "supercities" is associated with exponential growth from the last decade until 2030, where it is estimated that a series of mega-cities will be constituted (Khanna, 2016). This agglomeration of people will involve a large investment in infrastructure (high-speed trains, collection of big data - not forgetting data protection, as well as the protection of people's privacy -, etc.) associated with urban technological innovation.

It is worth noting how the growth of these "megacities" is raised in Asia (Kraas, 2007). Thus, economic growth in these coming years will come from markets in China, India and Southeast Asia (LeónLedesma, 2016). In this sense, it is expected to give a correct answer to the question, will poverty and lack of infrastructure affect the correct economic development of these societies? The answer is not clear due, precisely, to the existence of a clear social gap in these societies. However, although the increase in average wages, urban migration and a forecast of the increase in consumption may cause a boom in the middle class; This growth can encourage balance to be complicated. For this reason, governments can find themselves at the crossroads of fostering growth, without disrupting society.
Pero ¿qué implica la industria 4.0? La robótica, la Inteligencia Artificial (IA), Internet de las cosas (IoT), los datos masivos, las redes de comunicación social, las plataformas colaborativas, entre otros se asocian hacia una manera de actuar empresarial que les permiten enfrentarse a la globalización, a una competencia cada vez más intensa, a una mayor volatilidad en la demanda y a la necesidad de ser innovadores (tanto en producto, como organizacionalmente) (Francalanza et al., 2018; BelmanLópez et al., 2019; Torrent-Sellens, 2019).

A pesar de que los procesos laborales automatizados con una base digital pueden reemplazar el trabajo rutinario; la nueva realidad, caracterizada por la acumulación de capital, así como por el ahorro de costes, ha supuesto la generación de puestos de trabajo no automatizados. Todo ello considerando el debate asociado a la potencialidad del desplazamiento de los lugares de trabajo (Frey \& Osborne, 2017).

Por estos motivos, la tecnología se ha convertido en una importante herramienta que podría conducir a la mejora del bienestar social mediante proyectos de construir "ciudades inteligentes" en el contexto de las "mega-ciudades". El crecimiento de estas "superciudades" se asocia a un crecimiento exponencial desde la última década hasta el año 2030, donde se estima que se constituirán una serie de mega-ciudades (Khanna, 2016). Esta aglomeración de personas implicará una gran inversión en infraestructuras (trenes de alta velocidad, recopilación de macrodatos sin olvidar la protección de datos, así como la protección de la privacidad de las personas-, etc.) asociada a la innovación tecnológica urbana.

Cabe destacar cómo el crecimiento de estas "megaciudades" se enarbola en Asia (Kraas, 2007). Así, el crecimiento económico en estos años venideros provendrá de mercados de China, la India y el Sureste Asiático (León-Ledesma, 2016). En este sentido, se prevé dar una correcta respuesta a la pregunta ¿la pobreza y la falta de infraestructuras afectarán al correcto desarrollo económico de dichas sociedades? La respuesta no está clara debido, precisamente, a la existencia de una clara brecha social en dichas sociedades. No obstante, aunque el incremento de los salarios medios, la migración urbana y una previsión del aumento del consumo pueda provocar un auge de la clase media; este crecimiento puede fomentar que el equilibrio sea complicado. Por este motivo, los gobiernos se pueden encontrar en la encrucijada de potenciar el crecimiento, sin desajustar la sociedad. 
Also, another relevant area is the need for the need to mitigate the historical gap between women and men. In this sense, from the World Economic Forum, different measures are proposed to generate greater parity; These include greater participation and economic opportunities concerning women, educational achievements, health and political empowerment (Zahidi, 2020).

The latter acts as a basic pillar of the content of the World Forum; as well as the global well-being associated with environmental management, where all actors must act adequately and immediately. This debate revolves around a globalized system that determines the increasingly prominent gap between excluded and included. In this sense, this situation is framed within the increasingly perceptible globalization towards business, where there is a greater concentration of responsibilities of global economic power to large corporate holding companies, avoiding people and the environment.

As progress is made towards the future, it can be seen how there is a great dependence on nature and its services, since it generates the economic value of more than half of the world's GDP (WEF, 2020). That is why the overexploitation of nature carried out through historical unprecedented pressure can lead to the loss and slowdown of economic growth in the medium and long term (WEF, 2020).

Thus, future hope is steeped in the need to rethink the relationship between economic growth and nature, to reach a consensus of sustainable growth and avoid (and reverse), in this way, the unstoppable degradation that the natural world is suffering. In this context, the common interaction of both governments and individuals, as well as companies that have to pick up the glove thrown from the administration and society to carry out responsible actions, in which that decision-making must prevail mitigate the risks imposed on nature and, therefore, systematically limit its negative impact.

For this reason, since the World Economic Forum, a series of reports on the New Nature Economy have been released in 2020. These reports serve to clearly and in detail explain the main axioms that business and economic leaders can follow. to safeguard nature (WEF, 2020).
Asimismo, otro ámbito relevante es la necesidad de la necesidad de mitigar la brecha histórica entre mujerhombre. En este sentido, desde el Foro Económico Mundial, se proponen diferentes medidas para generar una mayor paridad; entre las cuales se destacan: mayor participación y oportunidades económicas con respecto a las mujeres, logros educativos, salud y empoderamiento político (Zahidi, 2020).

Esto último actúa como pilar básico del contenido del Foro Mundial; así como el bienestar global asociado a la gestión medioambiental, donde todos los actores deben actuar de manera adecuada e inmediata. Este debate gira en torno a un sistema globalizado que determina la cada vez más destacada brecha entre excluidos e incluidos. En este sentido, dicha situación se enmarca en la cada vez más perceptible globalización hacia los negocios, donde se da una mayor concentración de responsabilidades del poder económico global a los grandes holdings empresariales, obviando las personas y el medio ambiente.

Conforme se avanza hacia el futuro, se puede observar cómo existe una gran dependencia de la naturaleza y sus servicios, ya que esta genera un valor económico de más de la mitad del PIB mundial (WEF, 2020). Es por ello que la sobreexplotación de la naturaleza llevada a cabo mediante una presión sin precedentes históricos puede conllevar a la pérdida y ralentización del crecimiento económico a medio y largo plazo (WEF, 2020).

Así, la esperanza futura se empapa de la necesidad de repensar la relación entre crecimiento económico y la naturaleza, para poder llegar a un consenso de crecimiento sostenible y evitar (y revertir), de esta manera, la degradación imparable que está sufriendo el mundo natural. En este contexto es necesaria la interacción común, tanto de los gobiernos y de los individuos, como de las empresas que tienen que recoger el guante lanzado desde la administración y la sociedad para realizar acciones responsables, en las cuales deben imperar aquellas tomas de decisión que mitiguen los riesgos impuestos hacia la naturaleza y, por ende, limitar de manera sistemática su impacto negativo.

Por este motivo, desde el Foro Económico Mundial, se han lanzado una serie de informes sobre la Nueva Economía de la Naturaleza en 2020. Estos informes sirven para exponer de manera clara y detallada cuáles son los principales axiomas que pueden seguir los líderes empresariales y económicos para salvaguardar la naturaleza (WEF, 2020). 
Therefore, the need to bet on a global improvement in the positioning of economic and social actors is observed and for this, we must bet on taking advantage of human diversity to increase the range of ideas, seek a social value not Only economically, apply the science of change to generate constant change, know and learn to use the new technological systems (artificial intelligence, data, and other technologies) properly and, in this way, be able to generate dynamic advantages (Reeves, 2020). Therefore, it is at this moment that humanity is at a critical inflection point for the correct use of new technologies, as well as about the innovations that occur.

In this framework, the role of new technologies is of vital importance; which is why a proper development of it is required, avoiding always the potential to generate a digital divide that leads to poverty and social exclusion, not between societies, but between countries. A greater impact of research on the field of innovation is needed that can offer greater diffusion of technologies to all economies.

Finally, from the World Economic Forum, an attempt is made to open a door towards a more hopeful future that amplifies the main socio-economic issues towards greater penetration of global prosperity, avoiding geopolitical conflicts and generating a favorable environment to overcome future challenges (Berridge, 2010).
Por lo tanto, se observa la necesidad de apostar claramente por una mejora global del posicionamiento de los actores económicos y sociales y para ello, se debe apostar por aprovechar la diversidad humana con el fin de incrementar el rango de ideas, buscar un valor social no solo económico, aplicar la ciencia del cambio para generar un cambio constante, saber y aprender a utilizar de manera adecuada los nuevos sistemas tecnológicos (inteligencia artificial, datos y otras tecnologías) y, de esta manera, poder generar ventajas dinámicas (Reeves, 2020). Por lo tanto, es justo en este momento en el que la humanidad se encuentra en un punto de inflexión crítico con respecto a la correcta utilización de las nuevas tecnologías, así como en relación con las innovaciones que se producen.

En este entramado, el papel de las nuevas tecnologías es de vital importancia; razón por la cual se requiere un correcto desarrollo de este, evitando en todo momento la potencialidad de generar una brecha digital que conduzca a la pobreza y la exclusión social, ya no entre sociedades, sino entre países. Es necesario un mayor impacto de la investigación sobre el campo de la innovación que sea capaz de ofrecer una mayor difusión de las tecnologías a todas las economías.

Finalmente, desde el Foro Económico Mundial se intenta abrir una puerta hacia un futuro más esperanzador que amplifique las principales cuestiones socio-económicas hacia una mayor penetración de la prosperidad global, evitar los conflictos geopolíticos y generar un ambiente favorable para superar los desafíos futuros (Berridge, 2010).

\section{REFERENCIAS}

Belman-López, C.E., García, J. A. J. \& González, S. H. (2019).Análisis exhaustivo de los principios de diseño en el contexto de Industria 4.0, Revista Iberoamericana de Automática e Informática industrial, 1-15. DOI: 10.4995/riai.2020.12579 Berridge, G. (2010) Diplomacy: Theory and Practice. London, England: Palgrave.

Bodrozic, Z. \& Adler, P.S. (2018). The evolution of management models: A neo-Schumpeterian theory, Administrative Science Quarterly, 63, 85-129.

Francalanza, E., Borg, J. \& Constantinescu, C. (2018) Approaches for handling wicked manufacturing system design problems, Procedia CIRP, 67, 134-139. DOI: 10.1016/j.procir.2017.12.189

Frey, C.B. \& Osborne, M.A. (2017) The future of employment: How susceptible are jobs to computerization? Technological Forecasting \& Social Change, 114, 254-280.

Khanna, P. (2016) How megacities are changing the map of the world. In: https://www.ted.com/talks/parag khanna how megacities are changing the map of the world [Consulta: 3/02/2020].

Kraas, F. (2007) Megacities and global change in East, Southeast and South Asia. Asien, 103(4), 9-22.

León-Ledesma, M. A. (2016) Special Issue on Potential Growth and Misallocation in Asia. Asian Development Review, 33(2), 3-4.

Reeves, M. (2020) Así es como pueden competir las empresas en la década de 2020. Reunión Anual del Foro Económico Mundial. In: https://es.weforum.org/agenda/2020/01/asi-es-como-pueden-competir-las-empresas-en-la-decadade-2020/ [consulta: 3/02/2020]. 
Torrent-Sellens, J. (2019) Transformació digital i productivitat de l'empresa industrial a Catalunya: cap a la industria 4.0? Nota d'Economia, 105, 105-123.

World Economic Forum (WEF) (2020). Nature Risk Rising: Why the Crisis Engulfing Nature Matters for Business and the Economy. New Nature Economy Series. In: https://www.weforum.org/reports/nature-risk-rising-why-the-crisisengulfing-nature-matters-for-business-and-the-economy

Zahidi, S. (2020) Tres maneras de conseguir que la de 2020 sea la década en la que se cierre la brecha de género, Reunión Anual del Foro Económico Mundial. In: https://es.weforum.org/agenda/2020/01/tres-maneras-deconseguir-que-la-de-2020-sea-la-decada-en-la-que-se-cierre-la-brecha-de-genero/

\section{NOTAS DE LOS EDITORES}

This issue 18(2) of Dimensión Empresarial was finished being published at the beginning of the great crisis by COVID-19. This is very likely to change the ways of conceiving life, social relations and society itself. We are optimistic that this pandemic, like all those from which humanity has emerged, will be the possible turning point for a new rebirth of the species and a deepening of the construction of knowledge.

The 18 (2), corresponds to the second quarter of 2020 of Business Dimension. Between marches in Latin America, social conflict in several European regions, the coronavirus mentioned in the previous paragraph, endless wars such as those in the Middle East and Colombia, for example, crises in world trade scenarios, problems with the necessary environmental balances, among others of the circumstances through which national and international scenarios run are the causes of the instability present in almost the entire world; and, therefore, in companies, engines of the economic system, subjected to tensions with no solution in sight.

Consequently, it may be necessary to sharpen the innovative sense in all fields to find new solutions. Although the outlook is bleak, it highlights how some solutions have already advanced towards developments the size of the challenges, such as advances in the medical sector, articular intelligence, as well as the important commitment to space colonization.

An interesting question remains: what about the State, funder of innovation and entrepreneurship and instrument of socio-political mediations? This also requires a novel innovative process that provides it with the necessary functionality with a view to scenarios in which, the uncertainty derived from the scarce information today has been changed by the
Este número 18(2) de Dimensión Empresarial terminó de ser editado a comienzos de la gran crisis por el COVID-19. Esto es muy probable que trastocará las las maneras de concebir la vida, las relaciones sociales y la sociedad misma. Somos optimistas de que de esta pandemia, como de todas esas de las cuales la humanidad ha salido, será el posible punto de inflexión para un nuevo renacer de la especie y una profundización de la construcción de conocimiento.

El 18(2), corresponde al segundo trimestre de 2020 de Dimensión Empresarial. Entre marchas en América Latina, conflicto social en varias regiones europeas, el coronavirus citado en el párrafo anterior, guerras interminables como las de Medio Oriente y Colombia, por ejemplo, crisis en los escenarios comerciales mundiales, problemas con los necesarios equilibrios medioambientales, entre otras de las circunstancias por las cuales discurren los escenarios nacionales e internacionales son las causas de la inestabilidad presente en casi todo el orbe; $y$, por ende, en las empresas, motores del sistema económico, sometidas a tensiones sin solución a la vista.

Se puede requerir, en consecuencia, aguzar más el sentido innovador en todos los campos para encontrar nuevas soluciones. Aunque el panorama es sombrio, resalta como algunas soluciones ya han avanzado hacia desarrollos del tamaño de los retos, como los avances en el sector médico, la inteligencia articicial, así como la importante apuesta por la colonización espacial.

Deello queda un interesante interrogante: ¿yel Estado, financiador de la innovación y el emprendimiento e instrumento de las mediaciones socio-políticas qué? Este también requiere de un novedoso proceso innovador que lo dote de la funcionalidad necesaria con vista hacia unos escenarios en los cuales, la 
uncertainty of excess information, in addition to the complexity of all the theaters of human action.

This issue was published at the Universidad Autónoma del Caribe and Universidad del Pacífico. It is made up of eight articles, as follows: the editorial, six of the COLCIENCIAS scientific article typology and a free trial. The articles and editorial are presented, in order, in the following table.

On behalf of the Editorial, Scientific, Editing and Assistant Committees, we salute and acknowledge you for helping to generate knowledge for the Academic Community and for giving us the opportunity to be a means of expressing your findings. incertidumbre derivada de la información escaza hoy se ha cambiado por la incertidumbre del exceso de información, además de la complejización de todos los teatros de la acción humana.

Este número fue editado en la Universidad Autónoma del Caribe y la Universidad del Pacífico. Se compone de ocho artículos, así: el editorial, seis de la tipología de artículo científico de COLCIENCIAS y un ensayo libre. Los artículos y el editorial se presentan, en su orden, en la siguiente tabla.

A nombre de los Comités Editoriales, Científico, Editores y Asistentes nuestro saludo y reconocimiento por contribuir a generar conocimiento para la Comunidad Académica y por darnos la oportunidad de ser medio de expresión de sus hallazgos.

\begin{tabular}{|l|l|}
\hline \multicolumn{2}{|c|}{ Editorial } \\
\hline Albert-Por Miró, Guest Editor & World Economic Forum: present and future \\
\hline \multicolumn{2}{|c|}{ Results articles } \\
\hline Luis Araya Castillo \& Xavier Mendoza & $\begin{array}{l}\text { Internationalization process of Spanish firms of the } \\
\text { service sector }\end{array}$ \\
\hline $\begin{array}{l}\text { Andrea Estafanía Ramírez Gañan, Daniela Orozco } \\
\text { Quintero \& Manuel Alfonso Garzón Castrillón }\end{array}$ & $\begin{array}{l}\text { Management of happiness, subjective well-being and job } \\
\text { satisfaction }\end{array}$ \\
\hline Ricardo Prada & $\begin{array}{l}\text { Entrepreneurial attitude and success in the Colombian } \\
\text { auto parts sector }\end{array}$ \\
\hline $\begin{array}{l}\text { Fabiola Sáenz Blanco, Michael Steven Contento } \\
\text { Sepulveda \& Juana Mayerly Bautista Mendoza }\end{array}$ & $\begin{array}{l}\text { Variables and parameters of the Kano model applied to } \\
\text { health tourism }\end{array}$ \\
\hline $\begin{array}{l}\text { Hugo Alberto Rivera Rodríguez \& Wilson Omar González } \\
\text { Rodríguez }\end{array}$ & $\begin{array}{l}\text { People, change and innovations. Factor for business } \\
\text { lasting }\end{array}$ \\
\hline $\begin{array}{l}\text { Tomás José Fontalvo Herrera, Enrique de la Hoz \& Efraín } \\
\text { de la Hoz }\end{array}$ & Real Estate Sector Efficiency Analysis \\
\hline \multicolumn{2}{|c|}{ Free assay on science topics } \\
\hline Olcay Okun, Korhan Arun \& Suat Begec & Intrapreneurship and expectations restrictions \\
\hline
\end{tabular}

Néstor Juan Sanabria Landazábal Editor

Universidad Autónoma del Caribe

Colombia
Julio Cesar Acosta Prado

Editor

Universidad del Pacífico

Perú

Este artículo fue editado en la Facultad de Ciencias Administrativas, Económicas y Contables, www.uac.edu.co/ facultades/facultad-ciencias-administrativas-economicas-y-contables, de la Universidad Autónoma del Caribe, Barranquilla y la Facultad de Ciencias Empresariales, http://www.up.edu.pe/carreras-postgrado-idiomas/departamentosacademicos/administracion, de la Universidad del Pacífico, Lima. 